\title{
Malasseziosis Infection in a Dog
}

Ashwini $\mathbf{M}^{*}$

Veterinary Officer, MVSc (Veterinary Clinical Medicine), India

Submission: July 03, 2018; Published: July 26, 2018

*Corresponding author: Ashwini M, Veterinary Officer, MVSc (Veterinary Clinical Medicine), Hanabe, Doddaballapur, Bangalore North, India, Email: ashumohankumar@gmail.com

Abstract

A 5-year-old female Labrador was presented to Veterinary Dispensary with a complaint of hair fall, pruritus since one year. On clinical examination pruritus, alopecia, erythema and lichenification were observed. Faecal sample, wet film and blood smear examinations were negative. Microscopic examination of stained impression smear of affected area revealed budding yeast cells identified as Malassezia pachydermatitis. Terbinafine @ 30mg/kg bw per oral every 24 hrs for 2 weeks. Topical therapy with $2 \%$ ketaconozole once in 3 days was advised. The pet recovered uneventfully, and impression smear examination post treatment was found to be negative.

Keywords: Malasseziosis Infection; Dog; Ketaconozole; Terbinafine; Pachydermatitis; Oral mucosa; Vagina; Lichenification; Hyperpigmentation Microflora; Endocrinopathy; Pyoderma; Demodicosis; Keratinization disorders

\section{Introduction}

Malasseziosis infection is a common clinical condition in dogs caused by yeast Malassezia pachydermatitis. These organsims are normally present in low numbers in various region of dog body such as ear canal, perioral area, perineal region and moist skin folds [1]. Though the spp is common microflora of skin, the organism becomes pathogen in certain predisposing conditions such as food allergy, pyoderma, demodicosis, keratinization disorders, endocrinopathy, metabolic diseases, atopy and prolonged treatment with steroids. Otits externa is common complication of this condition [2].

\section{Case History and Observation}

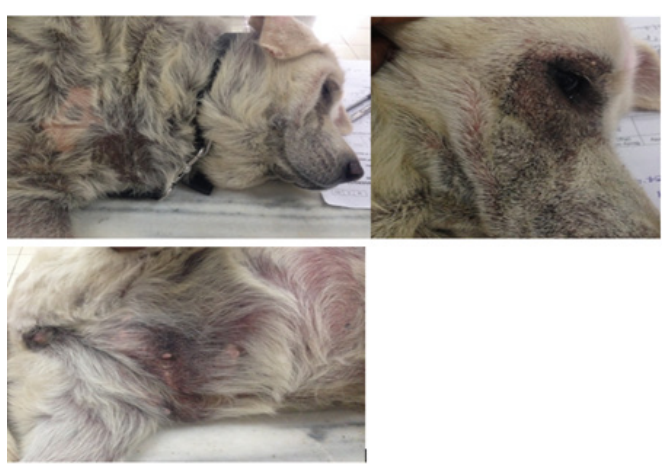

Figure 1: Skin scrapping

A 5-year-old female Labrador was presented to Veterinary Dispensary with a complaint of hair fall, itching for one year. The owner also reported that vaccination and deworming were regular. On clinical examination the pet had severe pruritus, alopecia and erythema on ventral abdomen, and thickening of skin. A musty odor was noticed along with lichenification. The lesions were also noticed on ventral neck, axilla and periorbital area (Figure 1). Oral and conjuctival visible mucous membranes were congested. Temperature was normal $\left(102^{\circ} \mathrm{F}\right)$.

Routine wet film examination and faecal examination were done to rule out microfilariosis and any intestinal parasitic infection respectively. Blood smear examination was also found to be negative. An Impression smear was obtained from areas affected. Cytology revealed round to oval budding yeast cells per high power field (Figure 2). Skin scrapping examination was found to be negative, thus ruling out concurrent demodicosis.

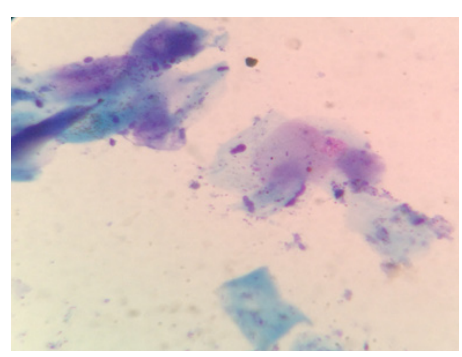

Figure 2: Cytology revealed round to oval budding yeast cells.

\section{Treatment and Discussion}

Diagnosis of Malasseziosis was made based on the clinical signs and the demonstration of the budding yeast cell. The organisms were observed as basophilic round to oval structures 
on impression smear. The dog was treated with terbinafine @ $30 \mathrm{mg} / \mathrm{kg}$ bw per oral every $24 \mathrm{hrs}$ for 2 weeks. Topical therapy with $2 \%$ ketaconozole once in 3 days was advised. The pet recovered uneventfully, and impression smear examination after 2 weeks was found to be negative for yeast cells.

Malassezia pachydermatitis is frequently isolated from the external ear canal, from the skin, particularly the anal area which could be a carriage zone, oral mucosa, vagina and eye of healthy dogs [3]. The lesions such as alopecia, lichenification, hyperpigmentation, erythema was like earlier reports [4]. The condition is always associated with a predisposing factor. The most common diseases acting as underlying causes of Malassezia dermatitis are allergies, pyoderma, demodicosis, keratinization disorders and endocrine disturbances. In the present study no such factor could be determined and hence there is likely chance that animal might be immunocompromised. Malassezia spp are sensitive to antifungal drugs such as terbinafine, ketoconazole and itraconazole [1]. Terbinafine @ 30mg/kg bw per oral every $24 \mathrm{hrs}$ was given along with topical therapy in this present case.

\section{References}

1. Hnilica KA (2006) Small animal dermatology: a color atlas and therapeutic guide. $\left(2^{\text {nd }}\right.$ edn), St Louis Mo. Saunders Elsevier, USA.

2. Nardoni S, Dini M, Taccini F, Mancianti F (2014) Diagnostic and clinical features of animal malasseziosis. Parassitologia 50: 81-83.

3. Scott DW, Miller WH, Griffin CE (2001) Muller \& Kirk's Small Animal Dermatology. WB Saunders, USA, pp. 363-374.

4. Nardoni S, Dini M, Taccini F, Mancianti F (2007) Occurrence, distribution and population size of Malassezia pachydermatis on skin and mucosae of atopic dogs. Vet Microbiol 122(1-2): 172-177.

\begin{tabular}{l} 
Your next submission with Juniper Publishers \\
will reach you the below assets \\
- Quality Editorial service \\
- Swift Peer Review \\
- Reprints availability \\
- E-prints Service \\
- Manuscript Podcast for convenient understanding \\
- Global attainment for your research \\
- Manuscript accessibility in different formats \\
( Pdf, E-pub, Full Text, Audio) \\
- Unceasing customer service \\
Track the below URL for one-step submission \\
https://juniperpublishers.com/online-submission.php \\
\hline
\end{tabular}

